\title{
Study of the spread of viral diseases based on modifications of the SIR model *
}

\author{
A.V. Nikitina ${ }^{1}$, I.A. Lyapunova ${ }^{1}$, E.A. Dudnikov ${ }^{1 * *}$ \\ ${ }^{1}$ Southern Federal University, Taganrog, Russian Federation
}

The spread of infectious diseases is a complex phenomenon with many interacting factors. The key role of mathematical epidemiology is to create pathogen spread patterns. These models serve as the mathematical basis for understanding the complex dynamics of the spread of the disease. There are various mathematical models of epidemics, but depending on the type of epidemic, there is a need for their careful analysis and improvement. In 1927, Kermak W. and Mackendrick A. published their theory, on the basis of which the SIR-model (Susceptible-Infected-Removed) was built. This theory was a hypothesis about the spread of an infectious disease among the population. This model has still not lost its relevance and is well suited for predicting the spread of infectious diseases. The aim of the work was to develop and study a mathematical model of the spread of the epidemic based on existing models of epidynamics.

The work investigated the processes of epidemics using the classical SIR model and its modifications: SEIRD models (Susceptible-Exposed-Infected-Removed-Dead) and SEIHFRmodels (Susceptible-Exposed-Infected-Hospitalized-Funeral-Removed). A numerical simulation of the dynamics of the spread of viral disease in various scenarios of its course has been carried out. The modern methods and means of mathematical modeling of the spread of viral diseases have been investigated; analyzed their effectiveness depending on the type of epidemic.

New modifications of well-known models based on systems of differential equations that take into account the characteristics of the acquisition of immunity, as well as the effect of delay in detecting infected people, are pro-posed. The sensitivity of the parameters included in the model is investigated.

The results can be used to study the processes of modern epidemics, including the coronavirus pandemic, as well as to effectively predict the dynamics of the disease, to develop effective mechanisms to contain and control epidemics of a local and global nature.

Keywords: mathematical model, principle of analogies, epidemic, susceptibility, infection, algorithm, software module.

Introduction. The beginning of the application of mathematical methods in the study of epidemics [1-9] was laid by Daniel Bernoulli in the middle of the 17th century (Bernoulli, 1760). He first used the simplest mathematical apparatus to evaluate the effectiveness of preventive vaccinations against smallpox. After this, a significant break followed, which culminated in the work of the English scientist William Farr. He studied and simulated statistics on the mortality rate of the Wales population from the smallpox epidemic in 1837-1839. For the first time, he managed to obtain mathematical models of indicators of the «movement» of the smallpox epidemic in the form of statistical patterns, which ultimately made it possible to develop a prognostic model of this epidemic. At the beginning of the 20th century, W. Farre's statistical approach to the study of

\footnotetext{
** The reported study was funded by RFBR, project number 19-31-51017.

${ }^{\square * *}$ E-mail: Nikitina.vm@gmail.com, setchan2009@gmail.com.
} 
epidemics was rethought and then developed in the work of John Brownley, who analyzed the statistical patterns of the «movement» of epidemiological indicators using little-known methods of mathematical statistics. However, this statistical approach to studying the patterns of epidemic development differs significantly from the analytical approach that was proposed at the end of the 19th century, first in Russia and then in England. Thanks to these researchers, at the beginning of the 20th century, the foundations of the modern theory of mathematical modeling of epidemics were formulated, the first prognostic models of epidemics (measles, chickenpox, malaria, etc.) were developed, their basic properties were studied, and analytical formulas for forecasting epidemics were obtained.

In the 1920s, the analytical approach was further developed. These theoretical works are still widely cited and used by scientists of the world in the analysis and prognosis of epidemics (outbreaks) of current infections (influenza and SARS; cholera and acute respiratory infections; parenteral hepatitis of groups B and C; HIV / AIDS, syphilis, gonorrhea, and a number of other infections). The SIR model of the spread of epidemics considered in this work belongs to this period of time [10-12].

With the advent of the first computers in the mid-1950s, the next stage in the development of epidemic models began to take shape. More and more complex mathematical models began to appear in the works of that time, in which random factors of the epidemic process played a significant role, so most of the models of this period were stochastic (probabilistic) in nature, and the working apparatus was the theory of probability and random processes. This stage in the development of modeling was associated with the «onslaught» of the epidemiology of «pure» mathematicians, who managed to create many abstract models, but with a very limited epidemiological content.

In the years 60-70, Western countries developed new types of deterministic and stochastic epidemic models aimed at studying the patterns of development of socially significant viral and bacterial infections. However, despite the high complexity of such models and the complexity of the mathematical apparatus, most of them were still abstract in nature, i.e. they were weakly associated with the formulation and solution of the practical problems of epidemiology. The fact is that the leading research centers for the study of epidemics in the United States and Western Europe at that time were in universities or in medical schools at universities that were quite far from the real problems of epidemiology, its real practice. In turn, epidemiologists poorly perceive abstract mathematical (deterministic or stochastic) models of epidemics and outbreaks and cannot combine them with practical needs [13-17].

The first studies that identified ways to bridge this gap were carried out in the $60 \mathrm{~s}$ in the USSR by academician O. Baroyan and professor L. Rvachev They developed a new methodology for mathematical modeling of epidemics - epidemiology. This methodology is based on the method of scientific analogy in mapping the epidemic process (the process of «transfer» of the pathogen from the patient to healthy) with the process of «transfer» of the substance (energy, momentum, etc.). It turned out to be especially relevant in the light of the Covid-19 pandemic (figure 1 shows the ratio of cases by country). 


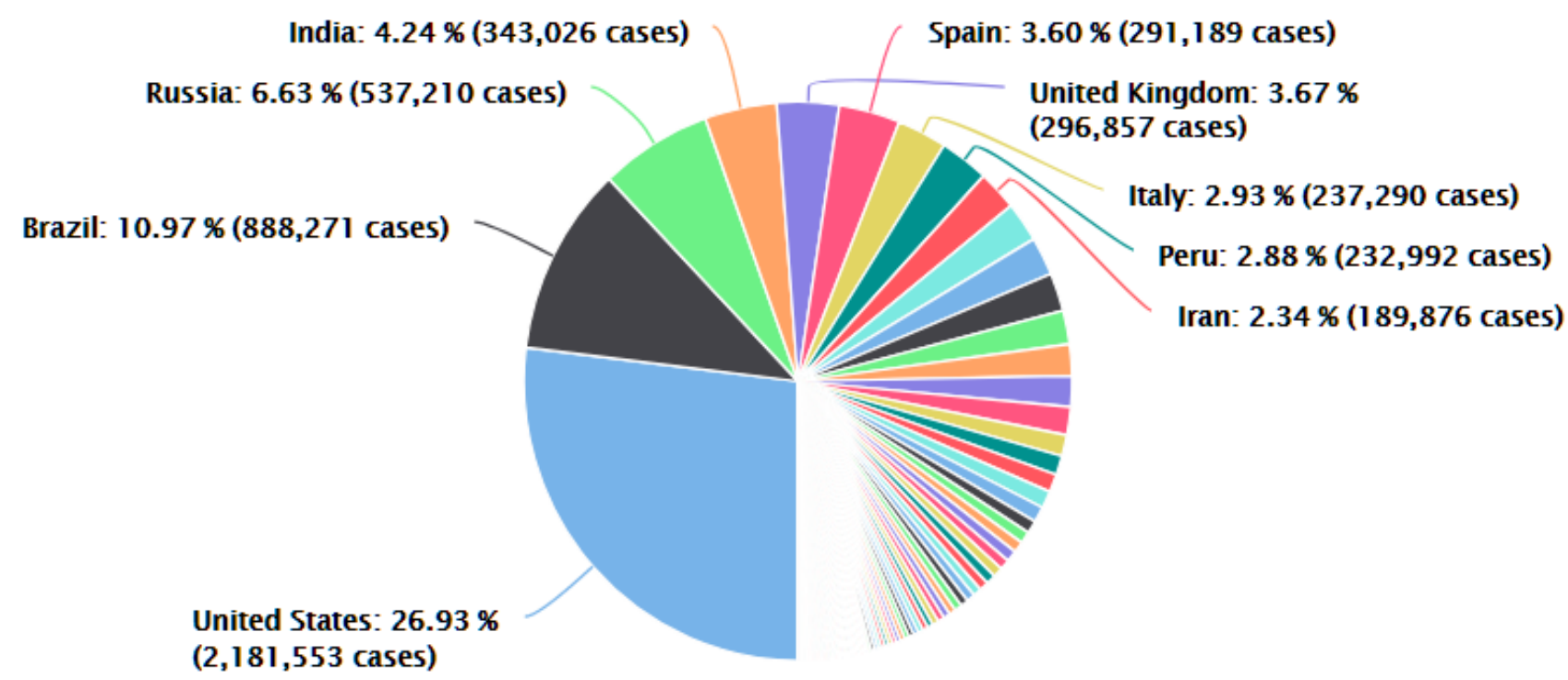

Fig. 1. The spread of coronavirus disease Covid-19 (https://www.worldometers.info)

Indeed, during the course of the development of the epidemic among the population of the territory affected by an infectious disease, a complex, self-sustaining process of «transfer» of the pathogen population to the community of susceptible people is formed [18-22]. The epidemiological content of this process is associated with its adequate display, both in the calendar time «t» and in the internal time « $\tau »$, which fixes the development of an infectious disease in many people affected by the infection. The system of equations that describes the development of the epidemic process is a system of non-linear partial differential equations with corresponding initial and boundary conditions that are very «similar» to the equations of hydrodynamics [23-25].

Mathematical modeling of diseases is a powerful tool for studying the mechanisms by which the disease spreads. Epidemiological models serve as the basis for predicting and assessing the dynamics of the spread of the disease. To contain and control the epidemic, it is important to consider high-quality and adequate mathematical models of the epidemic, which is currently feasible thanks to advances in mathematical modeling.

Materials and Methods. The study is based on the classical SIR model $[1-3,9,11]$, in which the population is divided into three classes:

- susceptible $S(t)$, used to refer to uninfected individuals or predisposed to the disease;

- infected $I(t)$, used to refer to infected individuals who are capable of spreading the disease;

- immune $R(t)$, used to refer to individuals who have been infected and dropped out of the class of infected as a result of recovery or death.

The population is considered fixed:

$$
S(t)+I(t)+R(t)=\text { const }=N \text {. }
$$

SIR model without birth and death rates:

$$
\frac{d S(t)}{d t}=\frac{-\beta S(t) I(t)}{N},
$$




$$
\begin{gathered}
\frac{d I(t)}{d t}=\frac{\beta S(t) I(t)}{N}-\gamma I(t), \\
\frac{d R(t)}{d t}=\gamma I(t),
\end{gathered}
$$

where $\beta$ is a coefficient showing the probability of getting diseases; $\gamma=1$ / T - coefficient reflecting the rate of recovery, $\mathrm{T}$ - time of the disease.

The initial conditions at time $\mathrm{t}=0$ are set as follows:

$$
S(0)=S_{0} \geq 0 ; I(0)=I_{0} \geq 0 ; R(0)=R_{0} \geq 0 .
$$

The right side of equation (1) describes the decrease in the population of susceptible people due to infection by infected people. The right side of equation (2) describes the increase in the population of infected people as a result of infection of susceptible people, taking into account the decrease in this population of infected people as a result of recovery or death of people. The right side of equation (3) describes the increase in the population of non-susceptible individuals as a result of recovery or death of those infected. A schematic of the SIR model is shown in figure 2.

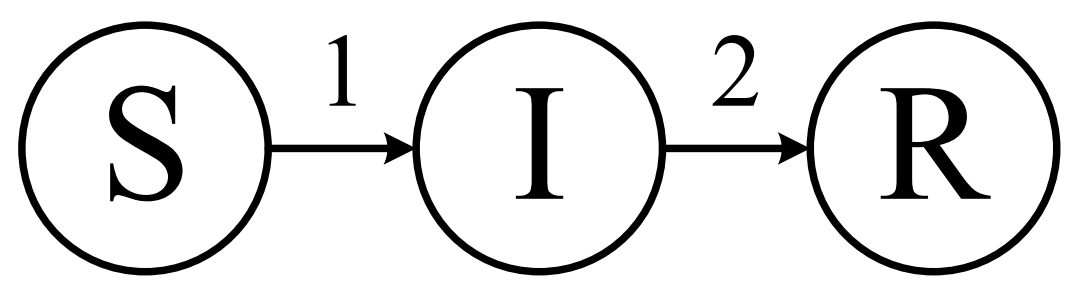

Fig. 2. The general scheme of the SIR model taking into account transitions between classes

It should be noted that the right-hand sides of equations (1), (2), (3) add up to zero, so that the total population size remains unchanged. This is an important property of this model. To preserve it, the recovered individuals and the dead fall into the class of immunity. This is a logical trick, because in both of these cases an individual cannot infect the rest of the population.

Also, in the classical SIR model, one can include the case of the influx of newborns into the class of susceptible individuals and the outflow of dead from the classes of susceptible, infected, and non-susceptible.

Suppose that $1 / \mu$ is the average life expectancy. The model can represent the following system of differential equations:

$$
\left\{\begin{array}{c}
\frac{d S(t)}{d t}=\frac{-\beta S(t) I(t)}{N}+\mu N-\mu S(t) \\
\frac{d I(t)}{d t}=\frac{\beta S(t) I(t)}{N}-\gamma I(t)-\mu I(t) \\
\frac{d R(t)}{d t}=\gamma I(t)-\mu R(t)
\end{array}\right.
$$

Initial conditions at time $\mathrm{t}=0$ :

$$
S(0)=S_{0} \geq 0 ; I(0)=I_{0} \geq 0 ; R(0)=R_{0} \geq 0,
$$

where $S_{0}, I_{0}, R_{0}$ is given. 
Results. To implement the SIR model and study the sensitivity of its parameters, we consider a period of 365 days. We introduce the following model parameters: $\beta=0,128, \gamma=0,09$, $N=6380000, \mu=0,0963, \delta=0,1, t_{0}=0, t_{1}=365, M=365$.

We set the vector of values of the initial number of the population, where $y_{1}=S_{0}=0,95 \mathrm{~N}$; $y_{2}=I_{0}=0,05 N ; y_{3}=R_{0}=0$.

The simulation results are presented in fig. 3 (the time is shown on the OX axis, red curves for the function $\mathrm{S}$ are plotted, blue for I, green for R).

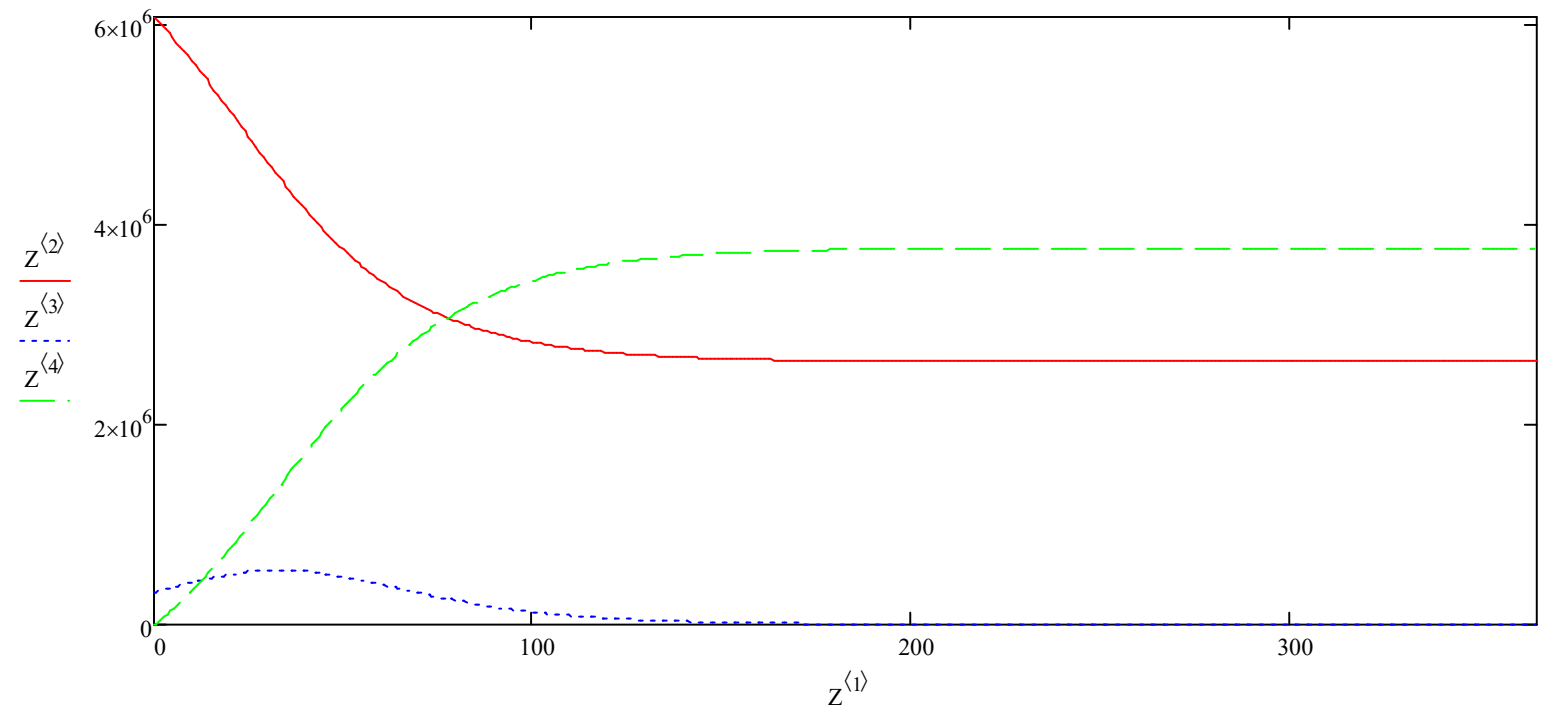

Fig. 3. The dynamics of susceptible, infected and unresponsive people with given infection parameters

Infectious diseases can have a latent or latent period of the disease. This is the period from the moment when a person is already infected to the onset of the first symptoms.

The SEIRD model considers the situation when a person is already infected, but the disease is in the latent period. In this model, the population is divided into five classes.

In addition to the considered $S(t)$ and $I(t)$, we define new classes as follows:

- latent $E(t)$, used to refer to individuals whose disease is in the incubation period;

- immune $\mathrm{R}(\mathrm{t})$, used to refer to recovered individuals;

- deceased D ( $\mathrm{t})$, used to refer to deceased individuals.

The outbreak population is considered fixed, $N=$ const. The SEIRD model can be expressed by the following system of differential equations: 


$$
\left\{\begin{array}{c}
\frac{d S(t)}{d t}=\frac{-\beta S(t) I(t)}{N}, \\
\frac{d E(t)}{d t}=\frac{\beta S(t) I(t)}{N}-\delta E(t), \\
\frac{d I(t)}{d t}=\delta E(t)-\gamma I(t)-\mu I(t), \\
\frac{d R(t)}{d t}=\gamma I(t), \\
\frac{d D(t)}{d t}=\mu I(t),
\end{array}\right.
$$

where the coefficients $\beta, \gamma$ correspond similarly to the SIR model; $1 / \delta$ is the average time of the latency period; $\mu$ is the mortality rate.

Initial conditions at time $\mathrm{t}=0$ :

$$
S(0)=S_{0} \geq 0 ; E(0)=E_{0} \geq 0 ; I(0)=I_{0} \geq 0 ; R(0)=R_{0} \geq 0 .
$$

We set the vector of values of the initial number of the population: $y_{1}=S_{0}=0,8 N ; y_{2}=E_{0}=0,15 N ; y_{3}=I_{0}=0,05 N ; y_{4}=R_{0}=0 ; y_{3}=D_{0}=0$.

The simulation results are presented in figure 4 (the time is shown on the OX axis, red curves are plotted for the function S, blue is plotted for I, green is plotted for R, and, respectively, dashed pink and blue are plotted for E and D).

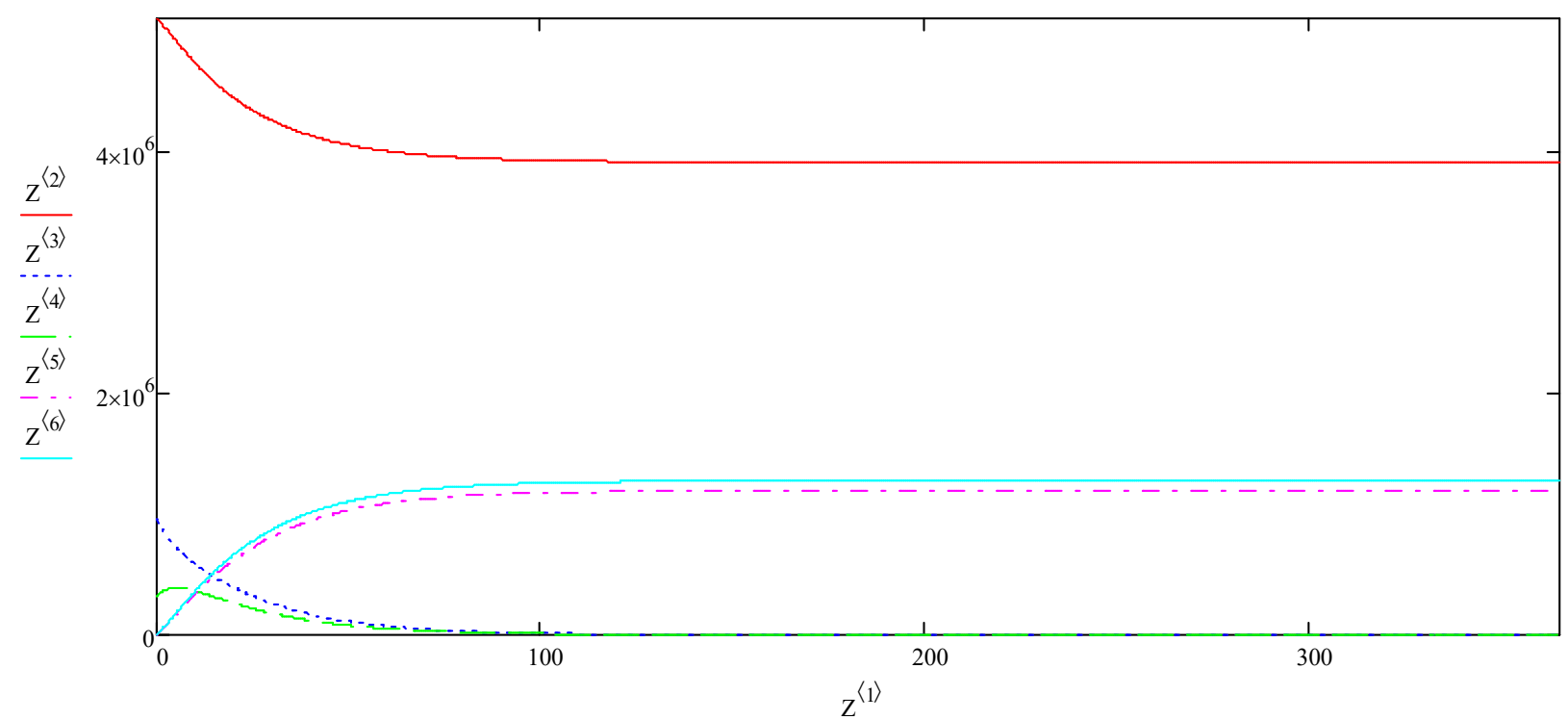

Fig. 4. Simulation result (5) for given infection parameters

As can be seen from the graph, the disease spreads less intensively, and the peak in the number of infected individuals occurs earlier in comparison with the SIR model, this is due to the lack of the ability to spread the disease and the duration of the incubation period in the class of latent individuals. This model more accurately describes the spread of the disease. 
The SEIHFR model was proposed by scientists from the University of Pierre and Mary Curie and describes the spread of the Ebola epidemic quite accurately, since this model includes all groups of people participating in the epidemic.

This model divides the population into six classes:

- susceptible $S(t)$, used to indicate the number of susceptible individuals at risk;

- latent $E(t)$, used to indicate the number of individuals whose disease is in the incubation period;

- infected $I(t)$, used to indicate the number of infected individuals capable of spreading the disease;

- hospitalized $H(t)$, used to indicate the number of individuals who have been hospitalized;

- unburied $F(t)$, used to indicate the number of individuals who have died but have not yet been buried;

- immune $R(t)$, used to refer to individuals who dropped out of the previous class as a result of recovery or death.

A susceptible individual $S$ can become latent $E$ after contact with infected $I$ and then move on to the class of infected $I$ after the incubation period of the disease. Some people infected with can be hospitalized $H$.

For people from class $I$ infected and hospitalized $H$, two outcomes are possible:

- people can die with the possibility of infecting others during the funeral $F$ and go into the class of immune $R$;

- individuals can recover and go into the class of non-susceptible $R$.

The SEIHFR model can be expressed as the following system of differential equations:

i

where: $\beta_{I}$ is the contact coefficient in the community; $\beta_{H}$ is the contact coefficient in the hospital; $\beta_{F}$ is the contact coefficient during the funeral; $\frac{1}{\alpha}$ is the average duration of the incubation period; $1 / \gamma_{H}$ is the average duration of the period from the onset of the first symptoms to hospitalization; $1 / \gamma_{D H}$ is the average duration of the period from hospitalization to death; $1 / \gamma_{I}$ is the average duration of the infectious period for the recovered; $1 / \gamma_{D}$ is the average duration of the infectious period for the deceased; $1 / \gamma_{I H}$ is the average duration of the period from hospitalization to recovery; $1 / \gamma_{F}$ is the average duration of the period from death to burial; $\theta$ is the proportion of hospitalizations; $\delta$ is the mortality rate.

The coefficients $\theta, \delta_{1}$ and $\delta_{2}$ are calculated by the following formulas:

$$
\theta_{1}=\frac{\theta\left(\gamma_{I}\left(1-\delta_{1}\right)+\gamma_{D} \delta_{1}\right)}{\theta\left(\gamma_{I}\left(1-\delta_{1}\right)+\gamma_{D} \delta_{1}\right)+(1-\theta) \gamma_{H}}, \delta_{1}=\frac{\theta \delta_{\gamma_{I}}}{\delta_{\gamma_{I}}+(1-\delta) \gamma_{D}}, \delta_{2}=\frac{\theta \delta_{\gamma_{H H}}}{\delta_{\gamma_{H}}+(1-\delta) \gamma_{D H}} .
$$

At time $\mathrm{t}=0$, set the initial conditions:

$$
\begin{gathered}
S(0)=S_{0} \geq 0 ; E(0)=E_{0} \geq 0 ; I(0)=I_{0} \geq 0 ; H(0)=H_{0} \geq 0 ; \\
F(0)=F_{0} \geq 0 ; R(0)=R_{0} \geq 0 .
\end{gathered}
$$

The population is considered fixed as follows:

$$
S(t)+E(t)+I(t)+H(t)+F(t)+R(t)=\text { const }=N .
$$


To study the model, vector values of the initial population number are set, where $y_{1}=S_{0}=0.8 \mathrm{~N} ; y_{2}=E_{0}=0.15 \mathrm{~N} ; y_{3}=I_{0}=0.05 \mathrm{~N} ; y_{4}=H_{0}=0 ; y_{5}=F_{0}=0 ; y_{6}=R_{0}=0$ :

Fig. 5 shows the simulation results (the time is shown on the OX axis, red curves are plotted for the function $S$, blue for $I$, green for $R$, blue for $D$, dashed pink and dashed brown for respectively $E$ and $H$ ).

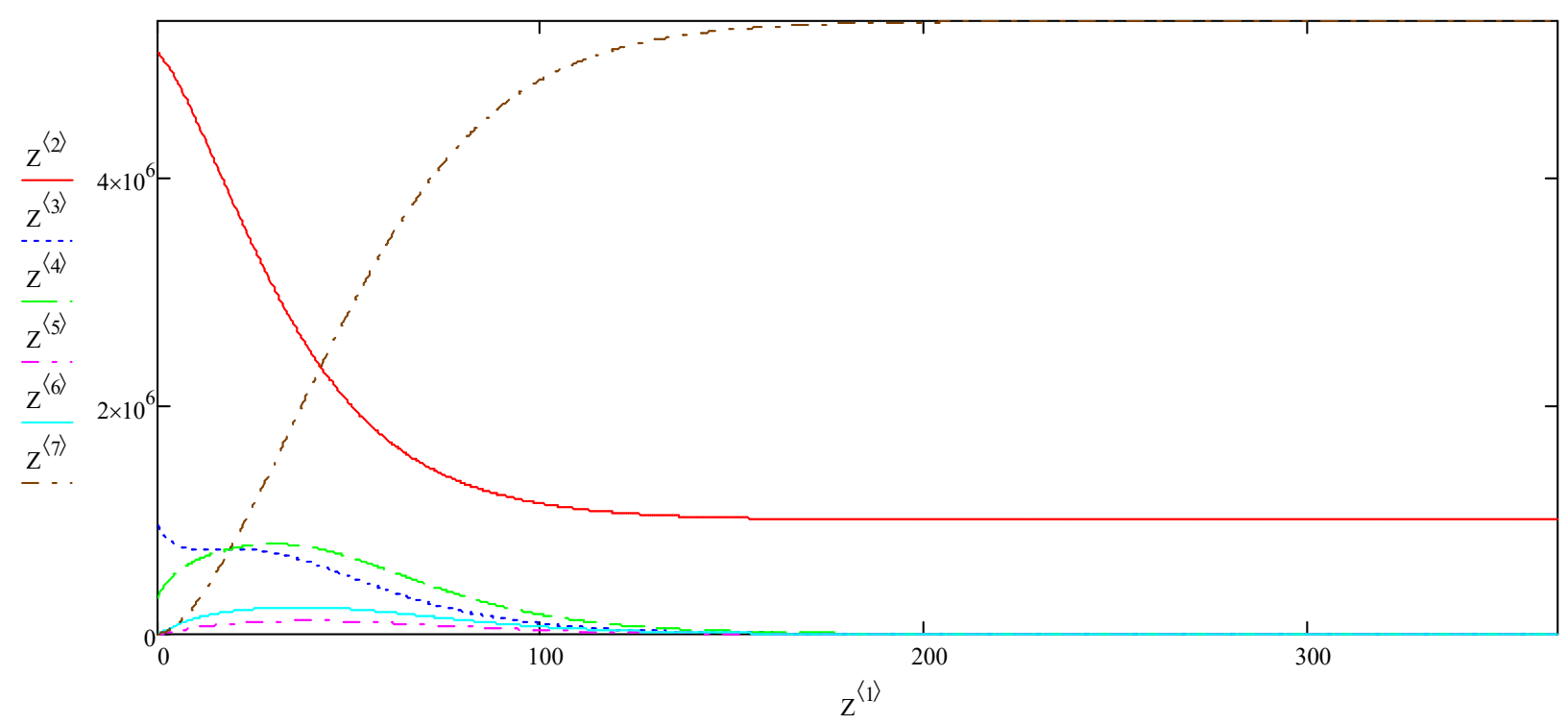

Fig. 6. Simulation result (6) for given infection parameters

As can be seen from the graphs presented, the majority of the population goes into the class of insensitive, thus we can conclude that even in the case of non-intervention, a significant part of the population ceases to be susceptible.

Discussion and Conclusions. In the absence of hidden individuals, a relatively large number of infected people lead to a relatively rapid and monotonous attenuation of the disease. The SIR model, on the one hand, can be easily analyzed and studied, but because of its simplicity it does not take into account a large number of important parameters and differs significantly in the results from other, more complex models, which makes many studies based on it divorced from reality.

The results of numerical modeling of the SEIRD model are very different from the results of other models: the epidemic lasts longer, its peak occurs earlier, and the number of deaths is much smaller. This is due to the fact that infected people die faster than they spread the disease, and at the time of the outbreak, the absence of hidden infected people is unlikely, which makes this class important for consideration. The SEIRD model also stands out among other models, since in it the process of transition of individuals to the class of deceased $D$ is considered only in a simplified order, which affected the modeling results.

The results of the numerical implementation of the SEIHFR model showed that, despite the extremely severe nature of the disease, the epidemic ends before the population dies out completely, while the number of losses among the population is extremely high (over 60\%). 
The considered modifications are most effective in epidemics of bacterial origin. As for viral epidemics, the picture is changing significantly. For example, an infection with Ebola occurs instantly and symptoms immediately appear, making the number of infected objects relatively easy to detect and control. In the case of an epidemic of coronavirus, the infection process proceeds unnoticed for some time, as a result of which the number of infected people grows faster, and the geography of infection expands significantly. Therefore, to further modify the SIR model, it is necessary to include a new parameter for describing infected people and take into account the delay effect when they are detected.

The results can be used to study the processes of modern epidemics and pandemics, as well as to effectively predict the dynamics of the incidence of viral infections, to develop effective mechanisms to contain and control epidemics, the spread of which can be local (the spread of the disease at the regional level) and global (for example, global coronavirus pandemic).

\section{References}

1. Yusuf T. T., Benyah F. Optimal control of vaccination and treatment for an SIR epidemiological model// World Journal of Modelling and Simulation, Vol. 8(2012). - No. 3. - pp. 194-204.

2. Bakare E. A., Nwagwo A., Danso-Addo E. Optimal control analysis of an SIR epidemic model with constant recruitment// International Journal of Applied Mathematical Research, 3 (3) (2014). pp. 273-285.

3. Sun Zh. Epidemic spreading survey// 8 February 2009.

4. Fischer C.S. America calling: A social history of the telephone to 1940. - University of California Press, 1992. - ISBN 978-0520086470.

5. $\quad$ Frisch H.L., Hammersley J.M. Percolation processes and related topics. // SIAM Journal on Applied Mathematics. - 1963. - Iss. 11(4). - pp. 894-918.

6. Granovetter M.S. Threshold Models of Collective Behavior // American Journal of Sociology. - 1978. - Iss. 83(6). - pp. 1420-1443.

8. Jackson M.O. Social and Economic Networks. - Princeton University Press, 2008. - ISBN 9781400833993.

9. Keeling M.J., Eames K.T.D. Network and epidemic models. // Journal of the Royal Society Interface. - 2005. - Vol. 2. - № 4. - pp. 295-307.

10. Kempe D., Kleinberg J., Tardos E. Maximizing the Spread of Influence through a Social Network. // Proceedings of the 9-th ACM SIGKDD International Conference on Knowledge Discovery and Data Mining, 2003. - pp. 137-146.

11. Kermack W.O., McKendrick A.G. A Contribution to the Mathematical Theory of Epidemics. // Proceedings of the Royal Society of London. Series A, Containing Papers of a Mathematical and Physical Character, 1927. - Vol. 115. - Iss. 772. - pp 700-721.

12. Kuperman M., Abramson G. Small world effect in an epidemiological model // Physical Review Letters. - 2001. - Vol. 86. - № 13. - pp. 2909-2912.

13. Markus M.L. Toward a «critical mass» theory of interactive media: Universal access, interdependence and diffusion. // Communication Research. - 1987. - Vol. 14. - № 5. - pp. 491-511.

14. Mikhailov A.S. Foundations of Synergetics I: Distributed active systems. Springer series in synergetics. - Springer, 1990.

$57-78$.

15. Morris S. Contagion // The Review of Economic Studies. - 2000. - Vol. 67. - № 1. - pp.

16. Rogers E.M. Diffusion of innovations, 5th Edition // Simon and Schuster, 2003. - ISBN 07432-5823-1. 
17. Rolfe M. Social Networks and Threshold Models of Collective Behavior. Preprint // Chicago: University of Chicago, 2004.

18. Ryan B., Gross N.C. The diffusion of hybrid seed corn in two Iowa communities // Rural Sociology- 1943. - Vol. 8. - pp. 15-24.

19. Strang D., Soule S. Diffusion in organizations and social movements: From hybrid corn to poison pills. // Annual Review of Sociology. - 1998. - Vol 24. - pp. 265-290.

20. Valente T. Network Models of the Diffusion of Innovations. - Cresskill, NJ: Hampton Press, 1995.

21. Williamson M. Epidemiological model of virus spread and cleanup / M. Williamson, J. Leveille // HP Laboratories Bristol (February 27th, 2003).

22. Daley, D.J. and Gani, J. Epidemic Modeling: An Introduction. Cambridge University Press, 1999.

23. Sukhinov A.I., Chistyakov A.E. Adaptive modified alternating triangular iterative method for solving grid equations with a non-self-adjoint operator // Mathematical Models and Computer Simulations. 2012. - Vol. 4. - No. 4. - pp. 398-409. DOI: 10.1134/S2070048212040084.

24. Gushchin V.A., Sukhinov A.I., Nikitina A.V., Chistyakov A.E., Semenyakina A.A. A model of Transport and Transformation of Biogenic Elements in the Coastal System and Its Numerical Implementation // Computational Mathematics and Mathematical Physics. 2018. - Vol. 58. - No. 8. - pp. 1316-1333. DOI: 10.1134/S0965542518080092.

25. Yakushev E.V., Sukhinov A.I., Lukashev Yu.F., Sapozhnikov F.V., Sergeev N.E., Skirta, A.Yu., Sorokin P.Yu., Soldatova E.V., Fomin S.Yu., Yakubenko V.G. Integrated oceanological studies of the Azov Sea on the 28th voyage of the rese.

\section{Authors:}

Alla V. Nikitina, Dr.Sci., professor, Professor of the Department of Intelligent and multiprocessor systems, South Federal University (Chekhov st., 2, Taganrog, Russian Federation), 8(951)516 85 38, nikitina.vm@gmail.com

Irina A. Lyapunova, Ph.Dr., associate professor of the Higher Mathematics Department, Southern Federal University (105/42 Bolshaya Sadovaya Str., Rostov-on-Don, 344006, Russia), ialyapunova@sfedu.ru

Evgeniy A. Ddudnikov, undergraduate student, Southern Federal University (105/42 Bolshaya Sadovaya Str., Rostov-on-Don, 344006, Russia), avnikitina@sfedu.ru 


\title{
Исследование процессов распространения вирусных заболеваний на базе модификаций SIR-модели *
}

\author{
А.В. Никитина ${ }^{1}$, И. А. Ляпунова ${ }^{1}$, Е.А. Дуников ${ }^{1 * *}$ \\ ${ }^{1}$ Южный федеральный университет, г. Таганрог, Российская Федерация
}

Распространение инфекционных заболеваний представляет собой сложное явление с множеством взаимодействующих факторов. Ключевая роль математической эпидемиологии заключается в создании моделей распространения патогенов. Эти модели служат в качестве математической основы для понимания сложной динамики распространения заболевания. Существуют различные математические модели эпидемий, но в зависимости от типа эпидемии возникает необходимость их тщательного анализа и совершенствования. В 1927 году Кермак У. и Маккендрик А. опубликовали свою теорию, на базе которой была построена SIR-модель (Susceptible-Infected-Removed). Данная теория представляла собой гипотезу о распространении инфекционного заболевания среди населения. Эта модель до сих пор не потеряла актуальности и хорошо подходит для прогнозирования процесса распространения инфекционных заболеваний.

Цель работы состояла в разработке и исследовании математической модели распространения эпидемии на основе существующих моделей эпиддинамики. В работе исследованы процессы протекания эпидемий с помощью классической SIR-модели и её модификаций: SEIRDмодели (Susceptible-Exposed-Infected-Removed-Dead) и SEIHFR-модели (Susceptible-ExposedInfected-Hospitalized-Funeral-Removed). Проведено численное моделирование динамики распространения вирусной болезни при различных сценариях ее протекания.

Исследованы современные методы и средства математического моделирования процессов распространения вирусных заболеваний; проанализирована их эффективность в зависимости от типа эпидемии. Предложены новые модификации известных моделей на основе систем дифференциальных уравнений, учитывающие особенности приобретения иммунитета, а также эффект запаздывания при обнаружении зараженных людей. Исследована чувствительность параметров, входящих в модели.

Полученные результаты могут быть использованы для исследования процессов протекания современных эпидемий, в том числе коронавирусной пандемии, а также для эффективного прогнозирования динамики заболеваемости, разработки эффективных механизмов сдерживания и контроля эпидемий локального и глобального характеров.

Keywords: математическая модель, принцип аналогий, эпидемия, восприимчивость, инфицирование, алгоритм, программный модуль.

\footnotetext{
־* Исследование выполнено при финансовой поддержке РФФИ в рамках научного проекта № 19-31-51017.

** E-mail: Nikitina.vm@gmail.com, setchan2009@gmail.com.
} 


\section{Авторы:}

Никитина Алла Валерьевна, Доктор технических наук, профессор, профессор кафедры Интеллектуальных и многопроцессорных систем, Южный федеральный университет (РФ, г. Таганрог, ул. Чехова, 2), 8(951)516 85 38, nikitina.vm@gmail.com

Ляпунова Ирина Артуровна, Кандидат технических наук, доцент кафедры высшей математики, Южный федеральный университет (РФ, г. Ростов-на-Дону, ул. Большая Садовая, 105/42), ialyapunova@sfedu.ru

Дудников Евгений Александрович, Магистрант, Южный федеральный университет (РФ, г. Ростов-на-Дону, ул. Большая Садовая, 105/42), avnikitina@sfedu.ru 